\title{
Making Print Tool Gambir Sap Parallel Slinder System
}

\author{
Jasman, Nelvi Erizon, Irzal and Junil Adri \\ Jurusan Teknik Mesin, Fakultas Teknik, Universitas Negeri Padang, Indonesia
}

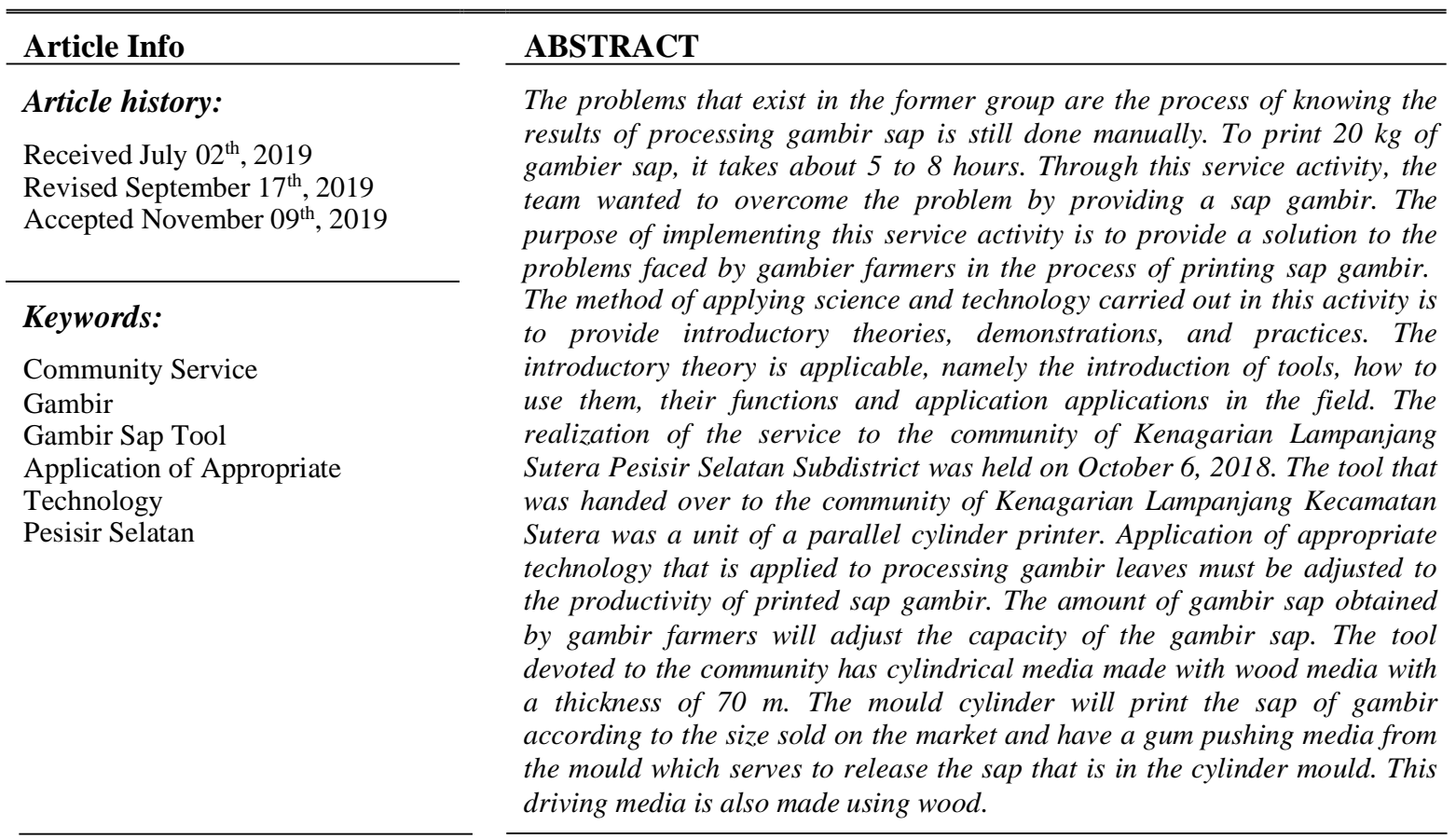

\section{Corresponding Author:}

Junil Adri

Jurusan Teknik Mesin, Fakultas Teknik Universitas Negeri Padang,

Jln. Prof. Dr Hamka Air Tawar, Padang (25131), Sumatera Barat, Indonesia

Email: juniladri@ft.unp.ac.id

\section{INTRODUCTION}

Gambir plants are known by the Latin name Uncaria gambir Roxb, the name English; Cat's Claw, Spanish name; Uña de Gato or Indian name; Vilcacora. Regional names for gambir in Indonesia, namely gambir. (Rukmana, 1994). Gambier plants (Uncaria gambir Roxb) commonly grow wild in the woods and other places that land slightly tilted and enough to get sunlight and even rainfall every year. It usually grows between $200 \mathrm{~m}-900 \mathrm{~m}$ above sea level. These plants are mostly located in Kalimantan and Sumatra. This plant is a shrub which has a hard stem that twists. The leaves are short-stemmed and light green. The flowers are white, small and round cob. The gambir part harvested is leaves and twigs which are then processed to produce economically valuable gambir extracts. [1]

Indonesia is the world's leading exporter of gambier. The export destinations of Indonesian gambier are Bangladesh, India, Pakistan, Singapore, Malaysia, Japan, and several European countries. Gambir is a traditional Indonesian commodity that has been cultivated since before World War I, especially outside Java such as West Sumatra, Riau Islands, South Sumatra (Bangka and Belitung), Aceh, West Kalimantan and Maluku. In Indonesia, gambir is mostly cultivated by West Sumatra farmers, which produce more than $80 \%$ of gambir production. The gambir producing centre is divided into two in West Sumatra, namely the northern centres in 50 cities, such as in Mahat District, Sembilan River, Pangkalan Koto Baru, and Kapur IX, while in the southern centres are in Pesisir Selatan District, precisely in Koto XI Sub-District until Silk [2]. 
West Sumatra generally has irregular cylindrical dry gambir with a concave in the middle (mortar) which has a diameter of $2.14 \mathrm{~cm}$ to $2.28 \mathrm{~cm}$ with a thickness (height) of $2.44 \mathrm{~cm}$ to $2.52 \mathrm{~cm}$, and the shape of the cylinder is not irregular with a diameter of $2.73 \mathrm{~cm}$ to $3.03 \mathrm{~cm}$ with a thickness of $2.60 \mathrm{~cm}$ to $2.95 \mathrm{~cm}$, while the coin-shaped dry gambier has a diameter of $4.50 \mathrm{~cm}$ and $1.84 \mathrm{~cm}$ thick. There is also a biscuit dried gambier with a size of $5 \mathrm{~cm} \times 5 \mathrm{~cm} \times 0.5 \mathrm{~cm}$ [3]. In the book [4], states that the Bootch type gambier has an average height of about $3.2 \mathrm{~cm}$ and a diameter of about $3.6 \mathrm{~cm}$, mortar with an average diameter of 3 $\mathrm{cm}$ and a height of $3.2 \mathrm{~cm}$, while for gambir the type of Stick has a size about $1 \mathrm{~cm} \times 1 \mathrm{~cm} \times 6 \mathrm{~cm}$ which is only produced in South Sumatra.

West Sumatra, one of the producers of dried gambier with prints that varies in each region. In the Regency of 50 Kota, it produces mortar gambir and in the area of Pesisir Selatan Regency produces coin gambir and boots. There are also wafer gambier blocks and biscuits in the city of Padang, which are the results of reprocessing from gambir from the two gambir producing regions. The reprocessing is to meet domestic demand with a small amount, and the rest is sent to Medan until it is exported out of Indonesia [5]. The dimensions produced from gambir production have been going on for generations. The problems that exist in the former group are the printing process. Printing is done using a mould made of bamboo (cup = Minangkabau), which has a diameter of about 1 inch. In West Sumatra, there are 3 types of moulds, consisting of cylindrical shapes, coins, and concave cylinders. For consumption purposes, Gambier is printed using concave cylindrical moulds, and for industrial/export purposes gambier is printed with a coin or cylindrical mould. [6] For 1 person who prints I kg gambir it takes 20-25 minutes. The process of printing the results of gambir sap processing is still done manually. To print $20 \mathrm{~kg}$ of gambier sap, it takes about 5 to 8 hours. The description of the manual printing process carried out by gambier farmers can be seen in the following figure.

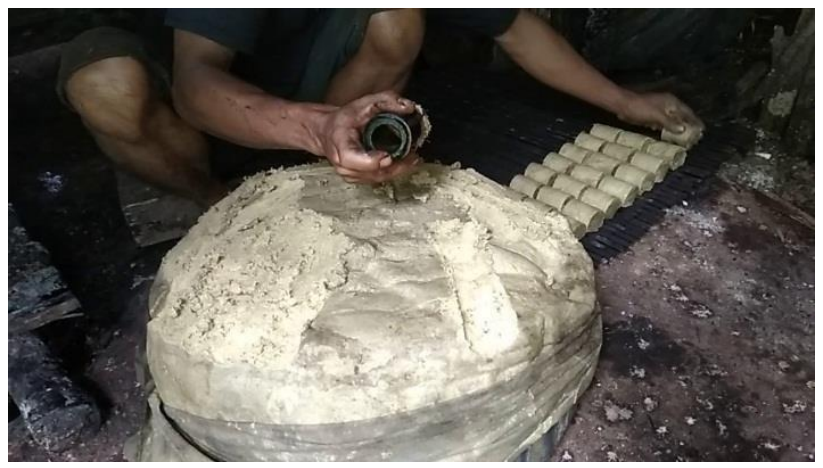

Figure 1 : Manual Printing Process

From figure 1, it can be seen how difficult and difficult the printing process is done by gambier farmers. Through this service activity, the team wanted to help farmers in overcoming this problem. The dedication team wanted to make a parallel cylindrical system printer capable of printing large amounts of gambier sap. This printing tool will make energy and time efficiency for farmers in processing gambier sap. The mechanism of the printer offered in this service activity is to design cylindrical printers which are arranged in parallel. The sap of the Gambir to be printed is put into the mould and pressed and removed into the drying pan by impacting it. The ability of this printing tool is designed to be able to print 50 items in each process. Thus the work of farmers in printing will be very fast and easy. The purpose of the implementation of this service activity is to provide a solution to the problems faced by the gambier company in the process of printing sap gambir. The length of time needed and the amount of energy that runs out during the printing process becomes the focus of the dedicated team in creating innovative printing tools sap gambir parallel cylinder system. The benefits obtained in this service activity were the implementation of the obligation of the tri dharma of the higher level of the dedication and assisted TEAM of gambir sap farmers in the process of printing sap gambir.

\section{METHOD}

The implementation of science and technology is done by providing demonstrations and direct applications in the field about how to do the printing process using a parallel cylinder printing device so that the production process of gambir sap can be increased and optimal. The mechanism of the printer offered in this service activity is to design cylindrical printers which are arranged in parallel. The sap of the Gambir to be printed is put into the mould and pressed and removed into the drying pan by impacting it. 
The ability of this printing tool is designed to be able to print 25 items in each process. Thus the work of farmers in printing will be very fast and easy.

The method of applying science and technology carried out in this activity is to provide introductory theories, demonstrations, and practices. The introductory theory is applicable, namely the introduction of tools, how to use them, their functions and application applications in the field.

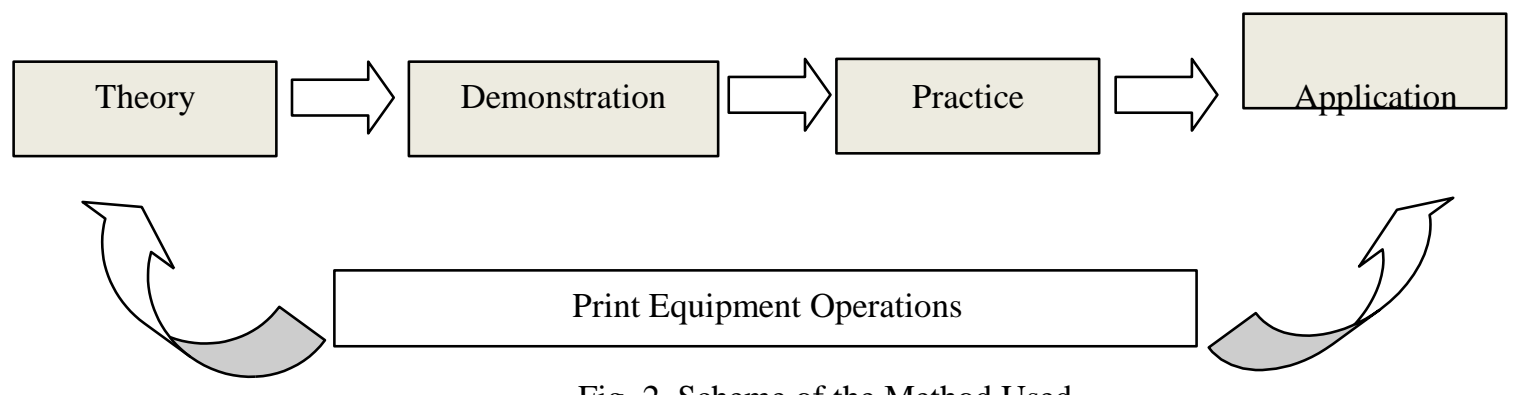

Fig. 2. Scheme of the Method Used

This method is adjusted to the schematic problem-solving framework. Problems arise because of various types of factors, the target audience is gambier farmers. In accordance with the objectives to be achieved in this activity is to produce farmers who are skilled and responsive to appropriate technology while also having the motivation to entrepreneurship, the method applied is by providing direct training to farmers to carry out various types of operational techniques for Gambir sap moulding.

The demonstration method in question is a method that provides a direct demonstration of how to use the correct gambir sap moulding in accordance with the specified techniques and procedures. Participants can immediately see, imitate and try the techniques and procedures to use gambir sap moulding in accordance with the established standard of operation. The method used in community service activities in farmer groups can be carried out using the following steps:

\subsection{Field Survey}

Field surveys were carried out to analyze the processing characteristics of sap gambir to be processed. The characteristics of the gambir sap in question include thickness, shape and dimensions to be printed. The survey was also conducted by looking directly at the process of printing gambir sap which was carried out by gambier farmers.

Application of appropriate technology that is applied to gambir leaf processing must be adjusted to the productivity of printed sap gambir. The amount of gambir sap obtained by gambir farmers will adjust the capacity of the gambir sap.

\subsection{Making a design of parallel cylinder systems on gambir sap moulding}

This design activity was carried out in the fabrication workshop of the FT-UNP Mechanical Engineering Department. In the design process this is done in several stages, namely:

1. Identify the characteristics of sap gambier.

2. Analyzing component components used

3. Determine the principle of working the machine

4. Determine the force used as a driver

5. Select materials that are suitable for machine construction

6. Make design drawings and detailed drawings of all engine components

7. Cutting material, forming, connecting and working on all engine components in accordance with working drawings. The process starts with making the engine frame, body, driving position, the transmission system used, and so on

8. Assembling engine components

9. Conduct several trials

\subsection{Target}

The target audience for this community service is gambier farmers in the Sutera District. 
Table 1. Program Activities that will be carried out on the Target audience

\begin{tabular}{|c|c|c|c|}
\hline No & Activities & Time & Information \\
\hline 1 & $\begin{array}{l}\text { Survey Location Activities to find out the characteristics } \\
\text { of sap gambier }\end{array}$ & 1 day & Team \\
\hline 2 & Discuss with devices of Nagari and target audiences & 1 day & Team and Device Nagari \\
\hline 3 & $\begin{array}{l}\text { Make a design of a parallel cylinder system on the } \\
\text { gambir sap moulding }\end{array}$ & 3 week & Team and Students \\
\hline 4 & Trial of gambir sap moulding operations & 1 week & Team and Students \\
\hline 5 & Check the process and printout of sap gambir & 2 week & Team and hall POM \\
\hline 6 & $\begin{array}{l}\text { Adjust the capacity, volume, diameter and height of the } \\
\text { cylinder, the pressing step and the pressure needed to } \\
\text { print sap gambier }\end{array}$ & 1 week & Team and Target Audience \\
\hline 7 & Demonstration of activities with the target audience & 1 day & Team and Target Audience \\
\hline 8 & $\begin{array}{l}\text { Application of appropriate technology for parallel } \\
\text { cylinder systems }\end{array}$ & 1 day & Team and Target Audience \\
\hline 9 & $\begin{array}{l}\text { Information dissemination for the community at the } \\
\text { location of community service activities }\end{array}$ & 1 day & Team and Target Audience \\
\hline
\end{tabular}

\section{RESULTS}

\subsection{Making Process}

The gambir latex printer was made in the Fabrication workshop of the Department of Mechanical Engineering, FT UNP. In the process of making a TEAM service tool involving two students. Benefits for students participating in this activity can be the final task which is one of the requirements to complete the student Diploma education. The stages of this manufacturing process are:

\subsubsection{Design of Gambir latex moulding machines}

The design process is done by using the 2008 version of the Autocad application. Job drawing is done by students. The design of this tool is made by using a jack as a pressure force. The design of the material to be used is to use stainless grey sterile food products.

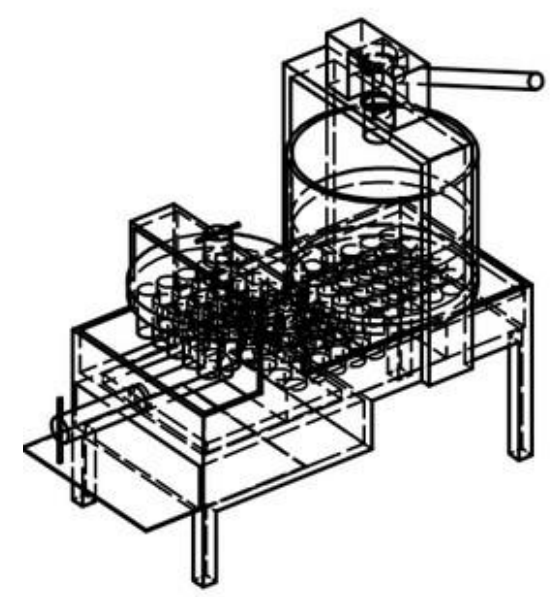

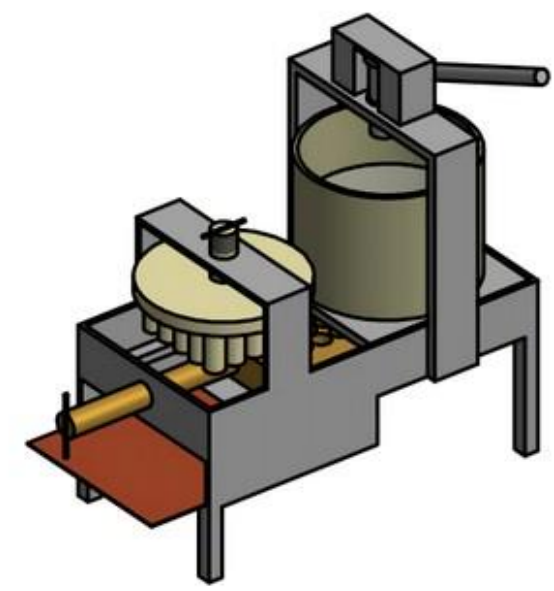

Fig. 3. Design Drawing

\subsubsection{Frame Making Process.}

The main frame on this gambir gum printing machine, made with an iron plate thickness of $4 \mathrm{~mm}$. This material selection is due to the multilevel frame design making the $4 \mathrm{~mm}$ plate selection more suitable for use. The dimensions of the frame for the moulding of the gum resin are $50 \times 70 \mathrm{~cm}$ in the frame with a press arm that will be used for the holder of the gum suppressor jack. Here is a picture of the frame making process. 


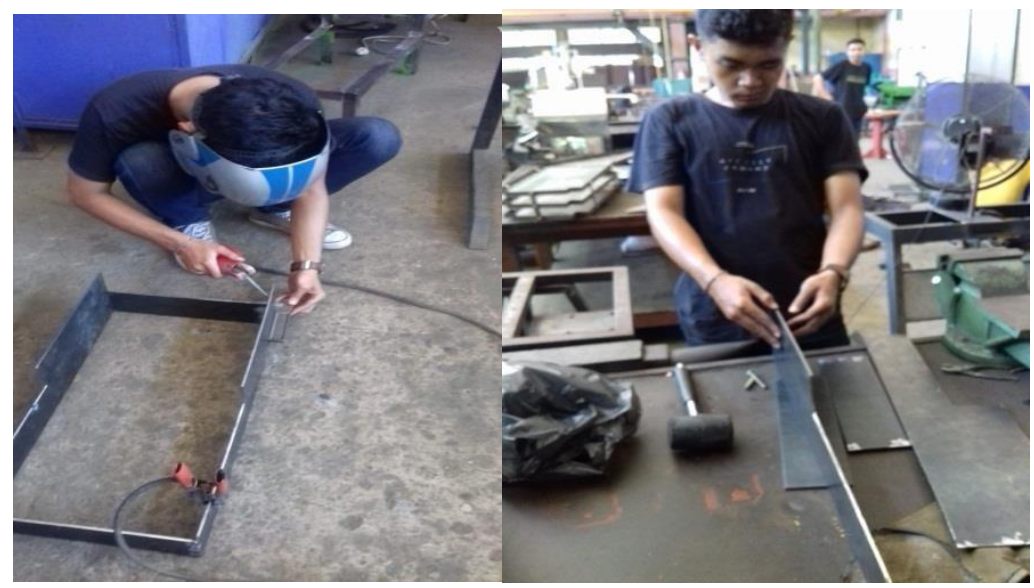

Fig. 4. Frame Making Process

\subsubsection{Making a Lifting Arm Sleeve}

The jack stand arm is made of $U$ profile iron size 50 x $50 \mathrm{~mm}$. The height of the jack stand arm is $50 \mathrm{~cm}$. The jack that will be used as a capacity of 30 tons. The following is the shape of the support arm that is made.

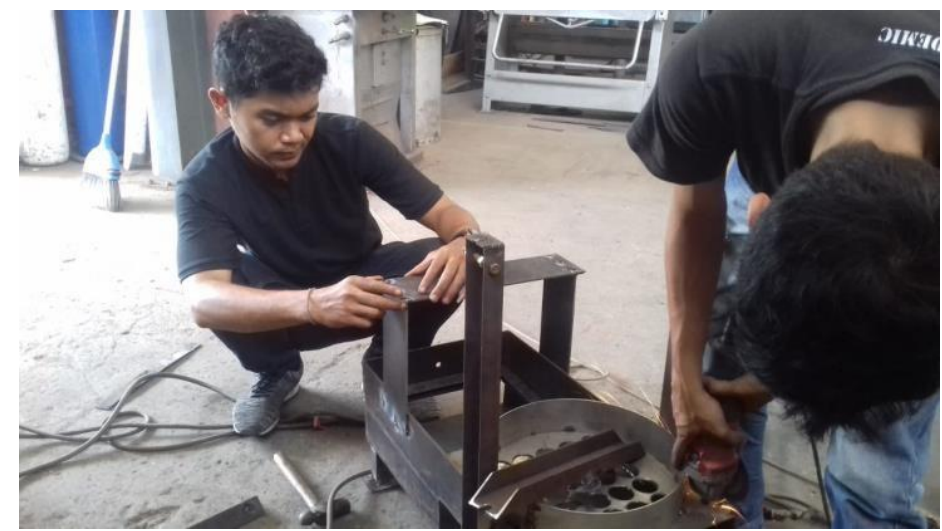

Fig. 5. Making the Lenk Stand

\subsubsection{Cylinder Making}

The cylinder functions as a gum container to be printed. Cylinders made $40 \mathrm{~cm}$ in diameter. the material used for the cylinder is a stainless plate thickness of $2 \mathrm{~mm}$. following the process of making slender.

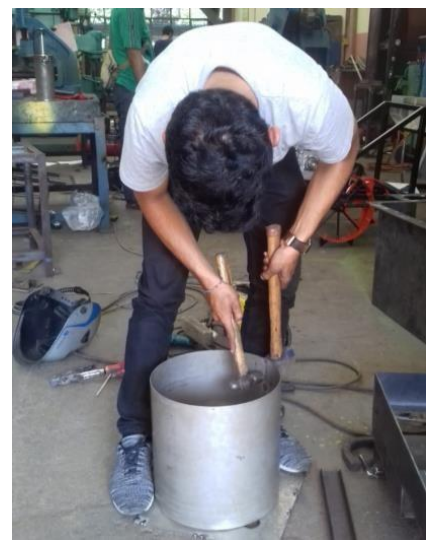

Fig. 6. Cylinder Making Process 


\subsubsection{Making Print Media}

Print media is made with a $4 \mathrm{~mm}$ stainless plate. Print media has holes that will function as the forming of sap gambier. The diameter of the hole is $40 \mathrm{~mm}$. the number of mould holes is 25 pieces. This makes the printing process more efficient and effective. The following is the process of producing print media.

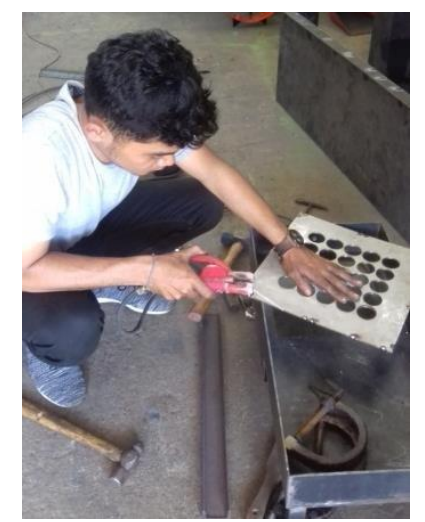

Fig. 7. Printing Media Making

\subsubsection{Manufacture of Mold Cylinders}

Mould cylinders are arranged in parallel. In this printing tool cylinder media is made with wood media with a thickness of $70 \mathrm{~mm}$. the mould cylinder will print sap gambir according to the size sold on the market.

\subsubsection{The Molding Media of Gum}

The sap push media from this mould serves to release the sap that is in the cylinder mould. This driving media is also made using wood.

\subsection{Implementation Results}

As the realization of community service, the delivery and counselling of the operation of the equipment have been implemented which is applied to the target audience in the Kenagarian Lampanjang Sutera Pesisir Selatan District.

The realization of service to the community of Kenagarian Lampanjang Sutera Pesisir Selatan District was held on October 6, 2018. The tool that was handed over to the community of Kenagarian Lampanjang Sutera District was in the form of a unit of parallel cylinder gambir system. This place of handover to the community is held at the Office of the Mayor of Nagari Kenagarian Lampanjang, Sutera Pesisir Selatan District.

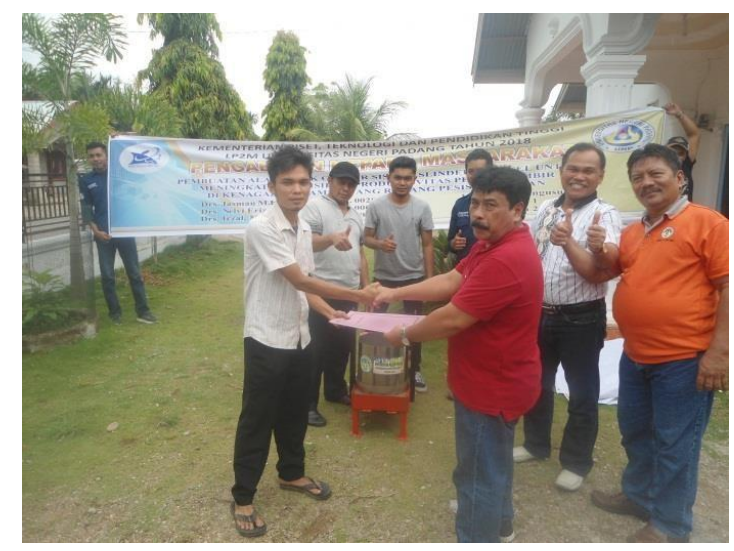

Fig. 8. Handover of community service

In addition to handover of the tools, demonstrations were also carried out on the operation of the equipment in front of the community, especially the gambier farmers. The demonstration in question is to provide a direct demonstration of how to use the correct gambir sap moulding in accordance with the specified techniques and procedures. The public can immediately see, imitate and try the techniques and procedures to use gambir sap moulding in accordance with established operational standards. 

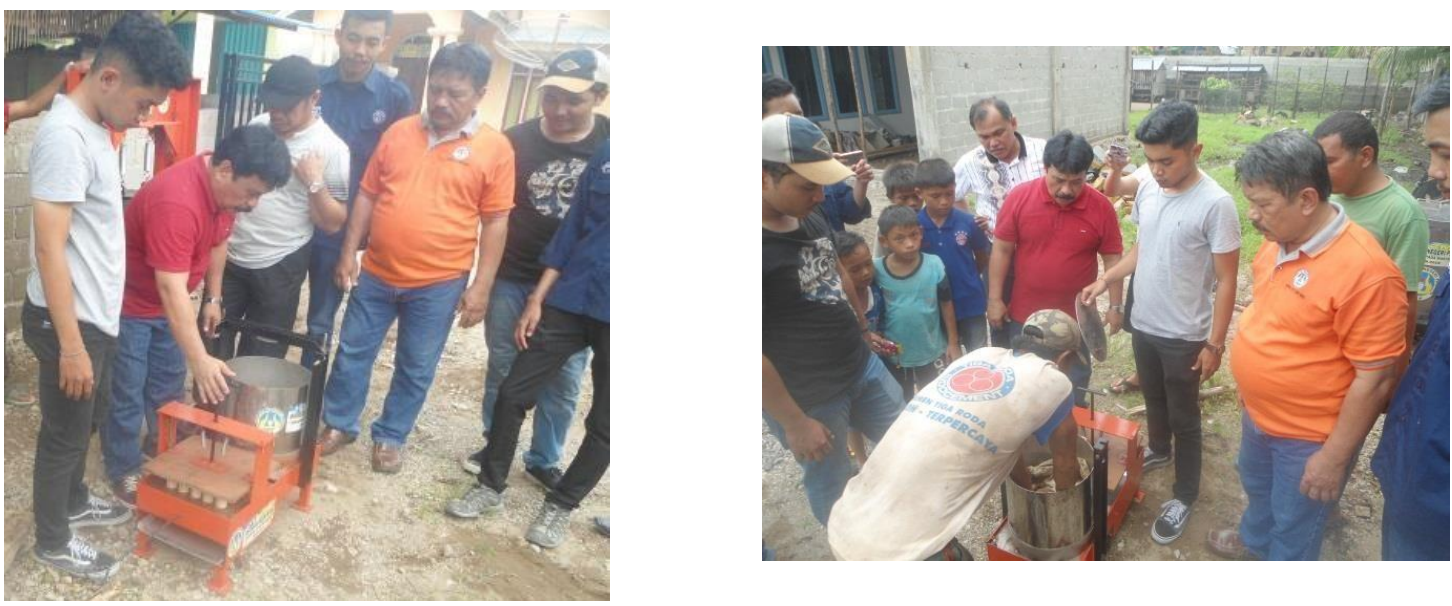

Fig. 9. The lecturer demonstrates how to use machine

Application of appropriate technology that is applied to processing gambir leaves must be adjusted to the productivity of printed sap gambir. The amount of gambir sap obtained by gambir farmers will adjust the capacity of the gambir sap. The tool devoted to the community has cylindrical media made with wood media with a thickness of $70 \mathrm{~mm}$. the mould cylinder will print the sap of gambir according to the size sold on the market and have a gum pushing media from the mould which serves to release the sap that is in the cylinder mould. This driving media is also made using wood.

\section{CONCLUSION}

Printing equipment uses a parallel cylinder system with 25 pieces of cylinders. The printing press process uses a 3-ton jack. This gambir sap moulding is assumed to make the printing process faster and more efficient.

\section{REFERENCES}

[1] Hiller K dan Melzig M.F., Die große Enzyklopaedie der Arzneipflanzen und. Drogen, Elsevier Spektrum Verlag, Heidelberg, (bagian kandungan bahan), Hoa, C.H.L., Cacacea, J.E., 2005

[2] Nazir, Peningkatan nilai tambah Gambir melalui diversifikasi produk, Badan Pelaksana Penyuluhan Pertanian, Perikanan dan Ketahanan Pangan Kabupaten 50 Kota, 2000

[3] Kasim et al., Pengolahan Hasil dan Kelayakan Usahatani Gambir (Uncaria gambir Roxb) di Kabupaten Lima Puluh Kota, Buletin TRO, 2005: 15 (1)

[4] Ahyarudin, A. Formulasi Obat Kumur Gambir (Uncaria gambir Roxb). Skripsi. Bogor: Fakultas Teknologi Pertanian, Institut Pertanian Bogor; 2009

[5] Amos, I., Zainuddin, B, Triputranto, S. Rusmandana, dan Ngudiwaluyo. Teknologi Pasca Panen Gambir. Jakarta: BPPT Press. 2004

[6] Daswir, dan I. Kusuma., Sistem Usaha tani gambir di Sumatera Barat. Media Komunikasi Penelitian dan Pengembangan Tanaman Industri. No. 11, Februari 1993; hal 68-74 